\title{
Medications and Lifestyles of Patients with Cardiovascular Risk Factors and/or Disease in Turkish Patients (MedLife-TR)
}

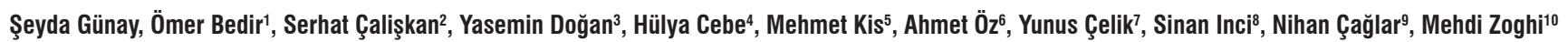
Department of Cardiology, Faculty of Medicine, Bursa Uludag University, Bursa, Turkey, ${ }^{1}$ Department of Cardiology, Cizre Dr. Selahattin Cizrelioglu State Hospital, Sırnak, Turkey, ${ }^{2}$ Department of Cardiology, Bahçelievler State Hospital, Istanbul, Turkey, ${ }^{3}$ Department of Cardiology, Kayseri Training and Research Hospital, Kayseri, Turkey, ${ }^{4}$ Department of Cardiology, Ercis State Hospital, Van, Turkey, ${ }^{5}$ Department of Cardiology, Silopi State Hospital, Sirnak, Turkey, ${ }^{6}$ Department of Cardiology, Istanbul Training and Research Hospital, Istanbul, Turkey, ${ }^{7}$ Department of Cardiology, Kırıkkale Yuksek Ihtisas Hospital, Kırıkkale, Turkey, ${ }^{8}$ Department of Cardiology, Faculty of Medicine, Aksaray University, Aksaray, Turkey, ${ }^{9}$ Department of Cardiology, Bakırkoy Dr Sadi Konuk Training and Research Hospital, İstanbul, Turkey, ${ }^{10}$ Department of Cardiology, Faculty of Medicine, Ege University, Izmir, Turkey ORCID:

Şeyda Günay: http://orcid.org/0000-0003-0012-345X

Ömer Bedir: http://orcid.org/0000-0002-2508-6707

Serhat Çalişkan: http://orcid.org/0000-0002-0260-5463

Yasemin Doğan: http://orcid.org/0000-0002-6507-9827

Hülya Cebe: http://orcid.org/0000-0003-1954-406X

Mehmet Kis: http://orcid.org/0000-0003-0775-8992

Ahmet Öz: http://orcid.org/0000-0003-0268-9641

Yunus Çelik: http://orcid.org/0000-0002-6307-8679

Sinan Inci: http://orcid.org/0000-0002-4576-128X

Nihan Çağlar: http://orcid.org/0000-0001-7925-2398

Mehdi Zoghi: http://orcid.org/0000-0002-8156-2675

\section{Abstract}

Background and Aim: Lifestyles and behavoiral patterns of patients must be known to improve public health and to prevent cardiovascular diseases (CVD). In this study, we aimed to provide insights into the lifestyles and behavioral patterns of patients applied to outpatient cardiology clinics in Turkey. Materials and Methods: The participants completed a self-administered questionnaire about awareness of cardiovascular (CV) risk factors and individual CV risk levels, lifestyles, and medications. Results: A total of 2793 patients, $52.1 \%$ of females with a mean age of $57.0 \pm 14.0$ years were included. The most common risk factor was hypertension. The most common CVD was coronary artery disease. The calculated CV risk level of 1041 patients $(37.3 \%)$ was high, while only $20.4 \%$ of all participants identified themselves as high risk. Participants were aware that hypertension, smoking, hyperlipidemia, diabetes, sedentary, family history, and aging were risk factors for CVD. About $44 \%$ of the patients reported that they used additional salt and the majority reported that they did not consume fast food. The most commonly prescribed CV drug was beta-blockers $(44.9 \%)$ and $22.4 \%$ of patients were taking minimum of 5 drugs daily. Conclusion: The awareness of CV risk factors and risk levels is low in the study population. Guideline recommended medications and lifestyle changes are not sufficiently implemented.

Keywords: Cardiovascular, health, lifestyle, public, risk, Turkish

\section{INTRODUCTION}

Cardiovascular diseases (CVD) are the leading cause of death and major burden on health care systems. $\cdot^{[1,2]} \mathrm{CVD}$ is primarily caused by metabolic, environmental, behavioral, and social risk

\section{Received: 06-06-2021 Revised: 01-09-2021 Accepted: 02-10-2021}

Published Online: 29-01-2022

\begin{tabular}{|l|l|}
\hline \multicolumn{3}{|c|}{ Access this article online } \\
\hline Quick Response Code: & Website: \\
& \\
http://www.ijcva.com
\end{tabular}

Address for correspondence: Dr. Şeyda Günay, Department of Cardiology, Faculty of Medicine, Uludag University, Görükle 16059, Bursa, Turkey. E-mail: seydagunaymedical@yahoo.com

This is an open access journal, and articles are distributed under the terms of the Creative Commons Attribution-NonCommercial-ShareAlike 4.0 License, which allows others to remix, tweak, and build upon the work non-commercially, as long as appropriate credit is given and the new creations are licensed under the identical terms.

For reprints contact: WKHLRPMedknow_reprints@wolterskluwer.com

How to cite this article: Günay Ş, Bedir Ö, Çalişkan S, Doğan Y, Cebe H, $\mathrm{Kis} \mathrm{M}$, et al. Medications and lifestyles of patients with cardiovascular risk factors and/or disease in turkish patients (MedLife-TR). Int J Cardiovasc Acad 2021;7:124-31. 
factors. There are well-known established risk factors such as diabetes mellitus, hypertension, hyperlipidemia, smoking, stress, and sedentary life. While genetic factors contribute to the onset and progression of CVD, we are now aware that many of the cardiovascular $(\mathrm{CV})$ risk factors are mediated by lifestyle. Diet, exercise, adherence to medications, sleep, and other environmental factors are also important to be healthy. Approximately $80 \%$ of heart disease, stroke, and Type 2 diabetes cases can be prevented by modifying undesirable lifestyle behaviors. ${ }^{[3,4]}$

A healthy lifestyle is well defined with a lower risk of $\mathrm{CV}$ and metabolic morbidity; hence lifestyle modification is a cardinal component of both personalized and public health. Several lifestyle intervention studies among patients at high risk revealed that changing lifestyle could reduce the risk of diabetes mellitus and improve CV health. ${ }^{[5-8]}$

The aim of this study was to provide insights into CV risk awareness, current lifestyle habits, drug usage, and medical behavioral patterns of Turkish patients with $\mathrm{CV}$ risk factors and/or diseases who admitted to outpatient cardiology clinics.

\section{Materials and Methods}

Patients admitted to the cardiology outpatient clinics for diagnostic or therapeutic purposes, who were over 18 years of age and agreed to participate in the study were included. The participants signed informed consent and completed a self-administered questionnaire in the following sections: baseline characteristics, awareness of $\mathrm{CV}$ risk factors and individual CV risk, lifestyle habits, medical behaviors, and CV medication. Patients from 27 hospitals in different regions of Turkey participated between November 2018 and March 2019.

On physical examination, pulse rate and blood pressure were recorded. Actual CV risk levels were calculated by the physicians according to the Framingham risk score which is a simplified and common tool for the assessment of risk level of CAD over 10 years. ${ }^{[9]}$ Office scale was used for weight measurements and body mass indexes were calculated by the formula recommended by the World Health Organization (ratio of weight and height, expressed as $\mathrm{kg} / \mathrm{m}^{2}$ ).

Patients performing at least $30 \mathrm{~min}$ of moderate exercise at least 3 days a week were defined as regular exercisers. Patients were considered hypertensive if they were on antihypertensive medications or had high blood pressure on examinations $(>140 / 90 \mathrm{mmHg})$, performed twice for confirmation. Blood pressure measurements were done as office measurements with validated digital sphygmomanometer. Patients were considered diabetic if they were using the antidiabetic medication, or had a fasting blood glucose higher than $126 \mathrm{mg} / \mathrm{dL}$. Hyperlipidemia was diagnosed if the patients were taking lipid-lowering drugs or their lipid levels were high according to the hyperlipidemia guidelines. ${ }^{[10]}$

History of $\mathrm{CV}$ interventions (percutaneous coronary interventions or bypass grafting), myocardial infarction, dysrhythmia, peripheral arterial disease, valvular heart disease (moderate or severe), cerebrovascular diseases, renal diseases, medication (including over the counter drugs) were questioned and noted after searching the medical records of study subjects.

The electrocardiography (ECG) of each patient was evaluated by the cardiologist.

\section{Ethical statement}

The study was performed in compliance with the Declaration of Helsinki. ${ }^{[1]]}$ and ethics approval was obtained from the local ethics committee of Istanbul Bakırkoy Dr. Sadi Konuk Training and Research Hospital (16/09/2019, 2019-18-07).

\section{Statistical analysis}

All statistical analysis was conducted using MedCalc Statistical Software version 18 (MedCalc Software bvba, Ostend, Belgium; http://www.medcalc.org; 2018). Continuous variables were presented as mean, standard deviation (SD), median, minimum and maximum values and data on frequency were presented as percentage (\%) for categorical variables. Chi-square analysis was used for correlation between categorical variables. Where appropriate, categorical variables were evaluated by Fisher exact and Fisher Freeman Halton Test. $P<0.05$ was considered statistically significant. The summary of data analysis was shared as tables. Since it was an observational, noninterventional study, there were no specific hypotheses to be tested, no comparisons and no endpoints.

\section{RESULTS}

\section{Baseline characteristics}

A total of 2793 patients, $52.1 \%$ female with a mean age of $57.0 \pm 14.0$ years were included. Only $10.5 \%$ of patients were university graduates. The most common risk factor was hypertension $(62.5 \%)$. The most common CVD was coronary artery disease with a prevalence of $35 \%$. On ECG, most of the patients had sinus rhytm $(93,3 \%)$ and atrial fibrillation prevalence was $6,3 \%$ [Table 1]. The mean systolic and diastolic blood pressure was $130.8 \pm 19.3 \mathrm{mmHg}, 78.1 \pm 11.4 \mathrm{mmHg}$ respectively.

\section{Cardiovascular risk awareness}

The calculated CV risk level of 1041 patients (37.3\%) was high and only $20.4 \%$ of all participants identified themselves as high risk [Table 2]. Although the risk factor with the highest awareness was hypertension, only $31.5 \%$ of the participants knew that it was a risk factor for CVD. Among participants, the ratio of awareness about $\mathrm{CV}$ risk factors was $22.5 \%$ for smoking, $18.0 \%$ for diabetes mellitus, and $10.6 \%$ for hyperlipidemia, $<10 \%$ of the participants knew that sedentary life, genetic history, and aging were also CV risk factors [Table 3].

\section{Lifestyle habits}

The mean body mass index was $28.4 \pm 4.9 \mathrm{~kg} / \mathrm{m}^{2}$, the rate of regular exercise was $35.8 \%$ [Table 4]. Most of the 


\begin{tabular}{|c|c|}
\hline Variable & $n(\%)$ \\
\hline \multicolumn{2}{|l|}{ Sex } \\
\hline Male & $1338(47.9)$ \\
\hline Female & $1455(52.1)$ \\
\hline \multicolumn{2}{|l|}{ Age (years) } \\
\hline $20-39$ & $354(12.7)$ \\
\hline $40-59$ & $1145(41)$ \\
\hline$\geq 60$ & $1294(46.3)$ \\
\hline \multicolumn{2}{|l|}{ Educational status } \\
\hline Primary-secondary school & $1360(48.7)$ \\
\hline High school & $446(16.0)$ \\
\hline University & $294(10.5)$ \\
\hline None & $693(24.8)$ \\
\hline \multicolumn{2}{|l|}{ Heart rhythm } \\
\hline Sinus & $2606(93.3)$ \\
\hline Atrai fibrillation & $175(6.3)$ \\
\hline Unknown & $12(0.4)$ \\
\hline \multicolumn{2}{|l|}{ Hyperlipidemia } \\
\hline Yes & $736(26.3)$ \\
\hline No & $2002(71.9)$ \\
\hline Unknown & $55(2.0)$ \\
\hline \multicolumn{2}{|l|}{ Hypertension } \\
\hline Yes & $1747(62.5)$ \\
\hline No & $1027(36.8)$ \\
\hline Unknown & $19(0.7)$ \\
\hline \multicolumn{2}{|l|}{ Smoking } \\
\hline Yes & $851(30.5)$ \\
\hline No & $1596(57.2)$ \\
\hline Unknown & $345(12.4)$ \\
\hline \multicolumn{2}{|l|}{ Diabetes mellitus } \\
\hline Yes & $751(26.9)$ \\
\hline No & $2035(72.9)$ \\
\hline Unknown & $7(0.2)$ \\
\hline \multicolumn{2}{|l|}{ Renal failure } \\
\hline Yes & $130(4.6)$ \\
\hline No & $2645(94.7)$ \\
\hline Unknown & $18(0.6)$ \\
\hline \multicolumn{2}{|l|}{ Coronary artery disease* } \\
\hline Yes & $978(35.0)$ \\
\hline No & $1798(64.4)$ \\
\hline Unknown & $17(0.6)$ \\
\hline \multicolumn{2}{|l|}{ Stroke/TIA } \\
\hline Yes & $124(4.4)$ \\
\hline No & $2646(94.8)$ \\
\hline Unknown & $22(0.8)$ \\
\hline \multicolumn{2}{|l|}{ Peripheral arterial disease } \\
\hline Yes & $65(2.3)$ \\
\hline No & $2680(96.0)$ \\
\hline Unknown & 47 (1.7) \\
\hline \multicolumn{2}{|l|}{ Heart failure } \\
\hline Yes & $367(13.1)$ \\
\hline No & $2335(83.1)$ \\
\hline Unknown & $91(3.3)$ \\
\hline
\end{tabular}

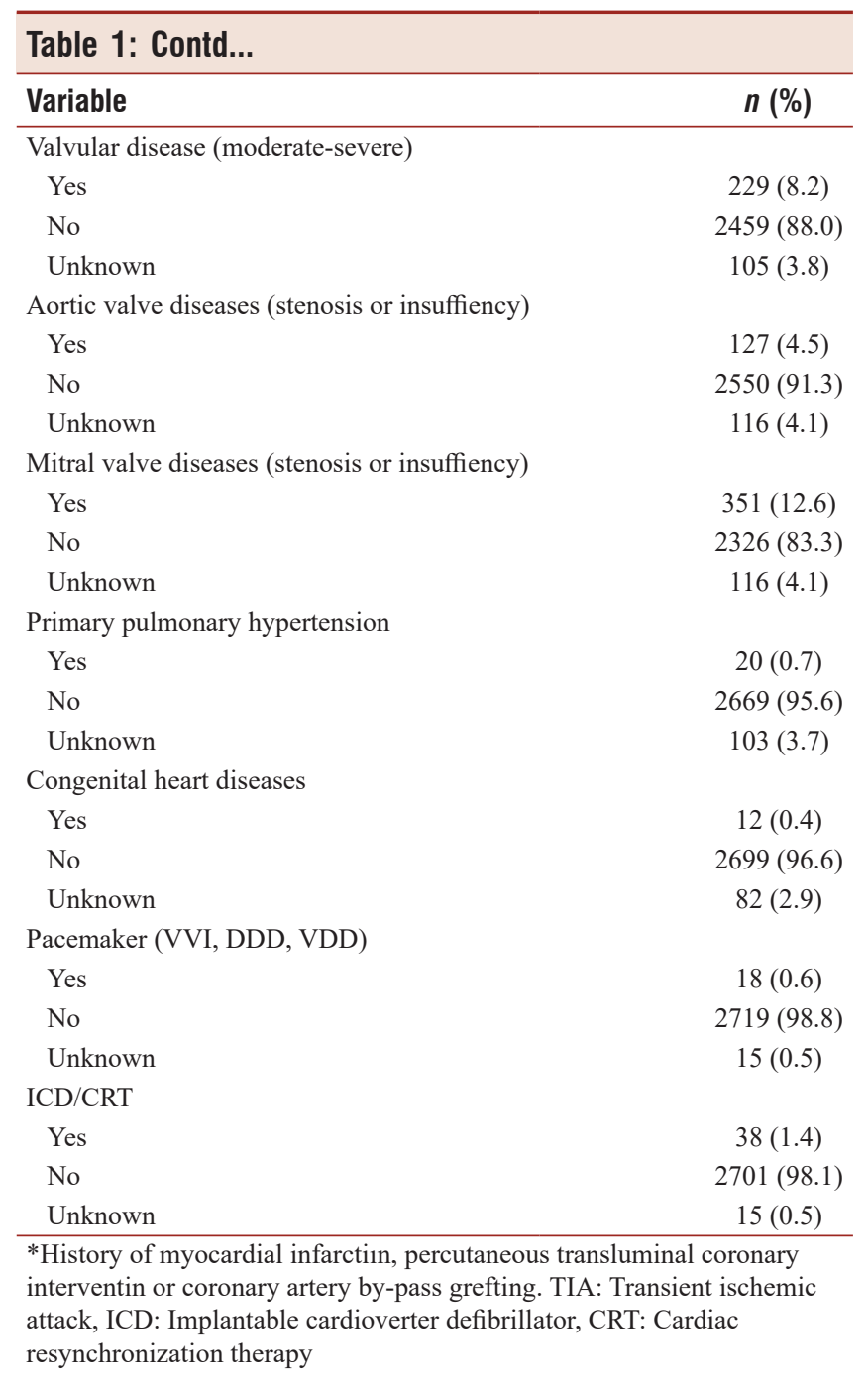

patients $(58.0 \%)$ stated that they did not skip any meal and didn't consume any fast food (53.9\%). The most consumed bread types were white $(61.0 \%)$ and bran $(13.9 \%)$ bread. The frequency of using additional table salt was $44.1 \%$. Despite $31.9 \%$ of the participants added no sugar to tea and/or coffee, $27.0 \%$ preferred 2 sugar cubes and $31.4 \%$ of them preferred 1 sugar cube. The herbal product and vitamin usage rates were low [Table 4].

\section{Medical attitudes and drug use}

Approximately one-third (36.7\%) of all participants used to visit outpatient clinics with an interval of 3-6 months. More than two-thirds of participants (76.7\%) get medical information from their doctors, not from medical television programs or Internet sources [Table 5]. When the drugs were examined, it was seen that only $7.6 \%$ of patients did not have a regular drug, whereas $70.0 \%$ of them were taking at least 1 drug daily and $22.5 \%$ of patients were taking more than 5 drugs per a day. Most of the patients $(80.0 \%)$ stated that they use their drugs regularly (defined as using a prescribed medication suggested by the medical doctor without interruption till recovery or change in medication) [Table 5]. The most commonly used 


\begin{tabular}{lc}
\hline Table 2: Assessment for cardiovascular risk & \\
\hline Variable & $\boldsymbol{n}(\%)$ \\
\hline Patients' self-reported cardiovascular risk level & \\
$\quad$ Low risk & $876(31.4)$ \\
Moderate risk & $1347(48.2)$ \\
High risk & $569(20.4)$ \\
Framingham risk level calculated by a physician & \\
Low risk & $823(29.5)$ \\
Moderate risk & $928(33.2)$ \\
High risk & $1041(37.3)$ \\
\hline
\end{tabular}

\begin{tabular}{lc}
\hline \multicolumn{2}{l}{ Table 3: Awareness of cardiovascular risk factors } \\
\hline Variable & $\boldsymbol{n}(\%)$ \\
\hline Hypertension & $880(31.5)$ \\
Hyperlipidemia & $296(10.6)$ \\
Smoking & $629(22.5)$ \\
Diabetes mellitus & $502(18.0)$ \\
Sedentary life & $172(6.2)$ \\
Heredity & $166(5.9)$ \\
Aging & $146(5.2)$ \\
\hline
\end{tabular}

drugs are shown in Table 6 . The most commonly prescribed CV drug was beta-blockers (44.9\%) followed by ASA (41.1\%), renin-angiotensin-aldosterone system blockers, and statins. The statins were believed to be harmful by $38.4 \%$ of participants. The most common non-CV medications were proton-pump inhibitors $(35.8 \%)$ and nonsteroidal anti-inflammatory drugs $(24.1 \%)$.

\section{Discussion}

In the present study, we found that the awareness of all CV risk factors is still low in our study population. In parallel with this, the calculated CV risk level of patients applied to cardiology outpatient clinics was high in most. CVD is the leading cause of death. ${ }^{[1]}$ Although there are well-known established $\mathrm{CV}$ risk factors such as diabetes mellitus, hypertension, and hyperlipidemia which increase the risk of CVD, the researchers also described behavioral risk factors as well as clinically measured risk factors. Nonsmoking, high-quality diet, and exercise are in relation to a lower risk of $\mathrm{CV}$ and metabolic diseases.

The prevalence of CV risk factors in a population may vary, influenced by changes in lifestyle and medical behavior over time. According to the International Diabetes Federation Diabetes Atlas, approximately half a billion people worldwide have diabetes mellitus, with the number expected to rise by $25 \%$ in 2030 and $51 \%$ in $2045 .{ }^{[12]}$ The prevalence of diabetes mellitus was reported to be $13.7 \%$ in the general Turkish population in the TURDEP study, ${ }^{[13]}$ in our study population it was $26.9 \%$. The reason for this difference may be the mentioned increase of global diabetes mellitus prevalence or the fact that our study was conducted among people who applied to cardiology outpatient clinics, and did not include the general population. While the rate of hyperlipidemia in population aged over 50 years was reported to be $32 \%$ by Onat et al.,$^{[14]}$ mean age $\pm \mathrm{SD}$ was $57.0 \pm 14.0$ years and hyperlipidemia prevalance was $26.3 \%$ in this study. Ozkara et al. showed that $75.4 \%$ of the population aged over 60 years was hypertensive. ${ }^{[15]}$ However, the mean age of our study population was under 60 years and $62.5 \%$ of the patients were hypertensive. On the other hand, smoking prevalence was higher in our study population (30.5\%) compared to the adult population (27.1\%) based on the World Health Organization. Global Adult Tobacco Survey. ${ }^{[16]}$

Previous studies revealed that adherence to some healthy lifestyles were associated with a decreased risk of major coronary events. ${ }^{[17]}$ At that point, the knowledge level of the population regarding healthy lifestyle and awareness of $\mathrm{CV}$ risk is important. Hence, American Heart Association works to reduce cardiac morbidity and mortality by improving public's knowledge level and management of modifiable risk factors. Our study results showed that the majority of Turkish patients who applied to the cardiology outpatient clinic did not know their individual CV risk levels correctly. Although $37.3 \%$ of all participants had a high CV risk, only $20.4 \%$ of them defined themselves as at high risk. This may result in them not making enough efforts to change their lifestyle and behavior patterns to improve their health. For this reason, the knowledge level of the patients should be increased. As the lifestyles, medical behaviors and CV risk awareness vary among different segments of the community, all healthcare professionals have a critical duty both in the screening of CV risk factors and in consulting for changing risky behaviors. Health-care providers should advise for lifestyle modification. ${ }^{[18,19]}$ Although it was evidenced that modifying medical behaviors improve health outcomes and reduce health-care costs, lifestyle counseling in physicians' offices is not routinely carried out, physicians give this kind of advice in only $34 \%$ of clinical visits. ${ }^{[20,21]}$ Our study results also showed that the primary source of medical information is physician visits. Therefore, during these visits, medical advice about dietary habits, smoking, and physical activity should be improved to achieve a healthy lifestyle and to prevent CVD.

When compared between developed and developing countries, lifestyles, medical behaviors, and CV risk awareness differ among communities and this may also contribute to the national differences in the prevalence of CVD. For example, when looking at food consumption, it is seen that the recommended amount of vegetables $(400 \mathrm{~g} /$ day) or fruit $(300 \mathrm{~g} /$ day) is consumed by only $0.4 \%$ of countries. Besides, only $20 \%$ of countries meet red meat consumption recommendations $\left(<100 \mathrm{~g} /\right.$ week). ${ }^{[22]}$ While recommended food intake goals ( $400 \mathrm{~g} /$ day for vegetables, $28.35 \mathrm{~g} /$ week for nuts/seeds, $50 \mathrm{~g} /$ day for whole grains, $100 \mathrm{~g} /$ week for seafood, $100 \mathrm{~g} /$ week for red meats) could not be achieved; fruit, nuts, and seed intake increased from 1990 to 2010, consuming whole grains decreased globally and the consumption of red meat also increased. ${ }^{[22]}$ Besides all these, to achieve an improvement in 


\begin{tabular}{|c|c|}
\hline Variable & $n(\%)$ \\
\hline \multicolumn{2}{|l|}{ Regular exercise* } \\
\hline Yes & $999(35.8)$ \\
\hline No & $1794(64.2)$ \\
\hline \multirow[t]{2}{*}{ Body mass index $\left(\mathrm{kg} / \mathrm{m}^{2}\right)$, mean $\pm \mathrm{SD}$} & 2791 \\
\hline & $28.42 \pm 4.98$ \\
\hline \multicolumn{2}{|l|}{ Consumption of herbal products } \\
\hline Yes & $397(14.2)$ \\
\hline No & $2395(85.8)$ \\
\hline \multicolumn{2}{|c|}{ Consumption of vitamins/nutritional supplements } \\
\hline Yes & $477(17.1)$ \\
\hline No & $2316(82.9)$ \\
\hline \multicolumn{2}{|c|}{ Number of sugar cubes used in tea or coffee } \\
\hline None & $890(31.9)$ \\
\hline 1 & $877(31.4)$ \\
\hline 2 & $753(27.0)$ \\
\hline 3 & $208(7.4)$ \\
\hline$>3$ & $65(2.33)$ \\
\hline \multicolumn{2}{|l|}{ Using additional table salt for meals } \\
\hline Yes & $1232(44.1)$ \\
\hline No & $1561(55.9)$ \\
\hline \multicolumn{2}{|l|}{ Type of preferred bread } \\
\hline White & $1703(61.0)$ \\
\hline Bran & $389(13.9)$ \\
\hline Rye & $130(4.6)$ \\
\hline Corn flour & $14(0.5)$ \\
\hline Whole wheat & $343(12.3)$ \\
\hline Farmhouse & $187(6.7)$ \\
\hline None & $27(1.0)$ \\
\hline \multicolumn{2}{|c|}{$\begin{array}{l}\text { Frequency of fast food consumption (hamburger, } \\
\text { pizza, French fries etc.) }\end{array}$} \\
\hline$>1$ time a week & $204(7.3)$ \\
\hline Once a week & $351(12.6)$ \\
\hline Once a month & $732(26.2)$ \\
\hline None & $1506(53.9)$ \\
\hline \multicolumn{2}{|l|}{ Number of meals per a day } \\
\hline 2 & $673(24.1)$ \\
\hline 3 & $1503(53.8)$ \\
\hline 5 & $617(22.1)$ \\
\hline \multicolumn{2}{|l|}{ Skipped meal } \\
\hline Breakfast & $258(9.2)$ \\
\hline Lunch & $767(27.5)$ \\
\hline Dinner & $148(5.3)$ \\
\hline None & $1620(58.0)$ \\
\hline
\end{tabular}

*3 days a week, at least $30 \mathrm{~min}$

public health, it must be kept in mind that it is recommended to focus not only on what should be eaten or not but also on public education, nutrition policies, and research. Countries should create cost-effective public health programs to address modifiable risk factors and minimize CVD-related disability and early death.

Public policies, educational initiatives or clinical interventions aimed at both improving healthy lifestyle awareness and changing medical behaviors should take place among the priority objectives. ${ }^{[23]}$ Unfortunately, the scientific communities

\begin{tabular}{lc}
\hline Table 5: Medical behaviours and drug usage of patients \\
\hline Variable & $\boldsymbol{n}(\%)$ \\
\hline Source of medical information & \\
Consulting a physcian & $2141(76.7)$ \\
TV programs & $208(7.4)$ \\
Newsletters and magazines & $22(0.8)$ \\
Searching the web & $180(6.4)$ \\
Not interested & $242(8.7)$ \\
Time interval for applying to a \\
healthcare professional (months) \\
$<3$ & \\
3 & $604(21.6)$ \\
$3-6$ & $856(30.7)$ \\
$>6$ & $1024(36.7)$ \\
Number of drugs used in a day & $308(11.0)$ \\
0 & \\
1 & $212(7.6)$ \\
2 & $380(13.6)$ \\
3 & $387(13.9)$ \\
4 & $438(15.7)$ \\
5 & $423(15.2)$ \\
$>5$ & $323(11.6)$ \\
Regular use of drugs & $627(22.5)$ \\
Yes & \\
No & $2218(80.0)$ \\
Opinion about statins & $554(20.0)$ \\
Not harmful & \\
No idea & $1072(38.4)$ \\
\hline & $1355(48.5)$ \\
& $365(13.1)$ \\
\hline
\end{tabular}

give inconsistent messages about nutrition and exercise. While healthcare professionals report that exercise improves $\mathrm{CV}$ health, there are also some controversial issues about intense endurance exercise and CV risk. ${ }^{[24]}$ However, over the past 30 years, significant gains have been made in tobacco control worldwide ${ }^{[25]}$ and smoking trends are better than diet and exercise trends.

In addition, another health problem is noncompliance with drug therapy. Despite effective therapies exist, adherence to drug schedules is still inadequate. Misinformation on the internet, television, and newspapers worsen drug compliance. In our study population, even if $80 \%$ of participants report that they use their drugs regularly, outpatient pharmacy data shows that only $43 \%$ of patients conform to statins, $40 \%$ to beta-blockers, and $38.8 \%$ to angiotensin-converting enzyme inhibitors or angiotensin receptor blockers. ${ }^{[26]}$ The figures in low-income countries are worse, for example, only $<5 \%$ of some Africans use statins given for secondary prevention. ${ }^{[27]}$

There are some limitations of this study. First, only patients who admitted to outpatient cardiology clinics were included in the study, hence the results may not reflect all segments of the society. Furthermore, we are aware about the fact that Framingham's risk score underestimates the risk status of patients under the age of 30 . Yet, to our knowledge, there are no validated risk scores in this age group Hence, all patients 


\begin{tabular}{|c|c|c|c|}
\hline \multicolumn{2}{|c|}{ Table 6: Medications of patients } & \multicolumn{2}{|l|}{ Table 6: Contd... } \\
\hline Drug & $n(\%)$ & Drug & $n(\%)$ \\
\hline ACE-i/ARB & & No & $2624(93.9)$ \\
\hline Yes & $619(22.2)$ & Unknown & $15(0.5)$ \\
\hline No & $2157(77.2)$ & Ranolazine & \\
\hline Unknown & $17(0.6)$ & Yes & $82(2.9)$ \\
\hline $\mathrm{BB}$ & & No & $2696(96.5)$ \\
\hline Yes & $1255(44.9)$ & Unknown & $15(0.5)$ \\
\hline No & $1518(543)$ & Statins & \\
\hline Unknown & $20(0.7)$ & Yes & $803(28.7)$ \\
\hline Ivabradin & & No & 1975 (70.7) \\
\hline Yes & $42(1.5)$ & Unknown & $15(0.5)$ \\
\hline No & $2730(97.7)$ & Ezetimibe & \\
\hline Unknown & $21(0.7)$ & Yes & $19(0.7)$ \\
\hline $\mathrm{CCB}$ & & No & $2759(98.8)$ \\
\hline Yes & $468(16.8)$ & Unknown & $15(0.5)$ \\
\hline No & $2310(82.7)$ & Fenofibrate & \\
\hline Unknown & $15(0.5)$ & Yes & $66(2.4)$ \\
\hline Diuretics (alone) & & No & $2712(97.1)$ \\
\hline Yes & $259(9.3)$ & Unknown & $15(0.5)$ \\
\hline No & $2519(90.2)$ & Omega-3fatty acids & \\
\hline Unknown & $15(0.5)$ & Yes & $15(0.5)$ \\
\hline Spironolactone & & No & $2763(98.9)$ \\
\hline Yes & $168(6.0)$ & Unknown & $15(0.5)$ \\
\hline No & $2610(93.5)$ & ASA & \\
\hline Unknown & $14(0.5)$ & Yes & $1148(41.1)$ \\
\hline Alfa blocker & & No & $1630(58.4)$ \\
\hline Yes & $77(2.8)$ & Unknown & $15(0.5)$ \\
\hline No & $2699(96.6)$ & Clopidogrel & \\
\hline Unknown & $17(0.6)$ & Yes & $366(13.1)$ \\
\hline Eplerenon & & No & $2412(86.4)$ \\
\hline Yes & $11(0.4)$ & Unknown & $15(0.5)$ \\
\hline No & $2767(99.1)$ & Prasugrel & \\
\hline Unknown & $15(0.5)$ & Yes & $22(0.8)$ \\
\hline RAAS blocker + CCB & & No & $2755(98.7)$ \\
\hline Yes & $204(7.03)$ & Unknown & $15(0.5)$ \\
\hline No & $2574(92.2)$ & Ticagrelor & \\
\hline Unknown & $15(0.5)$ & Yes & $63(2.3)$ \\
\hline RAAS blocker + diuretics & & No & $2715(97.2)$ \\
\hline Yes & $571(20.4)$ & Unknown & $15(0.5)$ \\
\hline No & $2207(79.0)$ & Warfarin & \\
\hline Unknown & $15(0.5)$ & Yes & $89(3.2)$ \\
\hline RAAS blocker $+\mathrm{CCB}+$ diuretics & & No & $2689(96.3)$ \\
\hline Yes & $30(1.1)$ & Unknown & $15(0.5)$ \\
\hline No & $2748(98.4)$ & NOAC & \\
\hline Unknown & $15(0.5)$ & Yes & $137(4.9)$ \\
\hline $\mathrm{BB}+$ diuretics & & No & $2641(94.6)$ \\
\hline Yes & $29(1.0)$ & Unknown & $15(0.5)$ \\
\hline No & $2749(98.4)$ & Oral antidiabetics & \\
\hline Unknown & $15(0.5)$ & Yes & $559(20.0)$ \\
\hline Long-acting nitrate & & No & $2219(79.4)$ \\
\hline Yes & $106(3.8)$ & Unknown & $15(0.5)$ \\
\hline No & $2671(95.6)$ & Insulin & \\
\hline Unknown & $16(0.6)$ & Yes & $214(7.7)$ \\
\hline Trimetazidine & & No & $2561(91.7)$ \\
\hline Yes & $154(5.5)$ & Unknown & $17(0.6)$ \\
\hline
\end{tabular}




\begin{tabular}{lc}
\hline Table 6: Contd... & \\
\hline Drug & $\boldsymbol{n}(\%)$ \\
\hline Amiodarone & \\
Yes & $21(0.7)$ \\
No & $2757(98.7)$ \\
Unknown & $15(0.5)$ \\
Class-1 antiarrhythmics & \\
Yes & $23(0.8)$ \\
No & $2754(98.6)$ \\
Unknown & $15(0.5)$ \\
Digoksin & \\
Yes & $65(2.4)$ \\
No & $2674(97.1)$ \\
Unknown & $15(0.5)$ \\
Antidepressants & \\
Yes & $223(8.1)$ \\
No & $2514(91.3)$ \\
Unknown & $17(0.6)$ \\
Oral NSAIDs (except ASA) & \\
Yes & $665(24.1)$ \\
No & $2072(75.2)$ \\
Unknown & $17(0.6)$ \\
PPIs & \\
Yes & $986(35.8)$ \\
No & $1752(63.6)$ \\
Unknown & $15(0.5)$ \\
\hline Yes: Taking the drug, No: Not taking the drug, ACE-i/ARB: & \\
Angiotensin-converting enzyme inhibitors/angiotensin receptor blockers, \\
CCB: Calcium channel blockers, RAAS: Renin-angiotensin aldosterone \\
system, ASA: Acetylsalicylic acid, NOAC: New oral anticoagulants, \\
PPIs: Proton-pump inhibitors, BB: Beta-blocker \\
$\quad$ \\
(n)
\end{tabular}

were evaluated according to Framingham's score. In addition, in some parts of the country, the fact that people speak different local languages may have affected the comprehensibility and accuracy of the questionnaire. Furthermore, access to medical records of some patients (especially echocardiography reports) was limited.

\section{Conclusion}

Despite these limitations, this study provides us valuable real-life data in terms of lifestyle habits, awareness of both CV risk factors and individual CV risk levels of patients admitted to cardiology outpatient clinics. The results obtained from this study could inspire researchers for future public health studies in the CV field.

\section{Acknowledgments}

This research was carried out with the contributions of the MedLlife -TR study clinical investigators (Hayati Eren, MD [Department of Cardiology, Elbistan State Hospital, Kahramanmaraş, Turkey], Hazar Harbalıoğlu, MD [Department of Cardiology, Düzca Atatürk State Hospital, Düzce, Turkey], Vahit Demir, MD [Department of Cardiology, Faculty of Medicine, Bozok University, Yozgat, Turkey], Lütfü Bekar, MD [Department of Cardiology, Faculty of Medicine, Hitit University, Çorum, Turkey], Tufan
Çınar, MD [Department of Cardiology, Sultan Abdulhamid Han Training and Research Hospital, İstanbul, Turkey], Mustafa Talha Güneş, MD [Department of Cardiology, Faculty of Medicine, Ege University, İzmir, Turkey], Veysel Ozan Tanik, MD [Department of Cardiology, Ankara Dışkapı Yıldırım Beyazit Training and Research Hospital, Ankara, Turkey], Dilay Karabulut, MD [Department of Cardiology, Bakırköy Dr Sadi Konuk Training and Research Hospital, İstanbul, Turkey], Mehmet Mustafa Yılmaz, MD [Department of Cardiology, Faculty of Medicine, Hitit University, Çorum, Turkey], Aslı Sönmez, MD [Department of Cardiology, Institute of Cardiology, Istanbul University, Istanbul, Turkey], Ali Çoner, MD [Department of Cardiology, Faculty of Medicine, Baskent University Alanya Application and Research Hospital, Antalya, Turkey], Assoc Prof Ozlem Arıcan Ozluk, MD [Department of Cardiology, Bursa Yuksek Ihtisas Training and Research Hospital, Bursa, Turkey], Hasan Kudat, MD [Department of Cardiology, Faculty of Medicine, Istanbul University, Istanbul, Turkey], Mustafa Yenerçağ, MD [Department of Cardiology, Samsun Training and Research Hospital, Samsun, Turkey], Bilal Çuğlan, MD [Department of Cardiology, Faculty of Medicine, Istinye University Liv Hospital, Istanbul, Turkey], Mustafa Kutay Y1ldırıml, MD [Department of Cardiology, Kızılay Hospital, Kayseri, Turkey], Gamze Çelik, MD [Department of Cardiology, American Hospital, Istanbul, Turkey]).

\section{Declaration of patient consent}

The authors certify that they have obtained all appropriate patient consent forms. In the form the patients have given their consent for clinical information to be reported in the journal. The patients understand that their names and initials will not be published and due efforts will be made to conceal their identity.

\section{Financial support and sponsorship}

Nil.

\section{Conflicts of interest}

There are no conflicts of interest.

\section{RefEREnCES}

1. Vos T, Lim SS, Abbafati C, Abbas KM, Abbasi M, Abbasifard M, et al. Global burden of 369 diseases and injuries in 204 countries and territories, 1990-2019: A systematic analysis for the global burden of disease study 2019. Lancet 2020;396:1204-22.

2. Mensah GA, Roth GA, Fuster V. The global burden of cardiovascular diseases and risk factors: 2020 and beyond. J Am Coll Cardiol 2019;74:2529-32.

3. Lloyd-Jones DM, Hong Y, Labarthe D, Mozaffarian D, Appel LJ, Van Horn L, et al. Defining and setting national goals for cardiovascular health promotion and disease reduction: The American Heart Association's strategic Impact Goal through 2020 and beyond. Circulation 2010;121:586-613.

4. Roger VL, Go AS, Lloyd-Jones DM, Benjamin EJ, Berry JD, Borden WB, et al. Heart disease and stroke statistics - 2012 update: A report from the American Heart Association. Circulation 2012;125:e2-20.

5. Lindström J, Ilanne-Parikka P, Peltonen M, Aunola S, Eriksson JG, Hemiö K, et al. Sustained reduction in the incidence of type 2 diabetes by lifestyle intervention: Follow-up of the Finnish Diabetes Prevention Study. Lancet 2006;368:1673-9. 
6. Li G, Zhang P, Wang J, Gregg EW, Yang W, Gong Q, et al. The long-term effect of lifestyle interventions to prevent diabetes in the China da qing diabetes prevention study: A 20-year follow-up study. Lancet 2008;371:1783-9.

7. Li G, Zhang P, Wang J, An Y, Gong Q, Gregg EW, et al. Cardiovascular mortality, all-cause mortality, and diabetes incidence after lifestyle intervention for people with impaired glucose tolerance in the da qing diabetes prevention study: A 23-year follow-up study. Lancet Diabetes Endocrinol 2014;2:474-80.

8. Estruch R, Ros E, Salas-Salvadó J, Covas MI, Corella D, Arós F, et al. Primary prevention of cardiovascular disease with a mediterranean diet. N Engl J Med 2013;368:1279-90.

9. Wannamethee SG, ShaperAG, Lennon L, Morris RW. Metabolic syndrome vs framingham risk score for prediction of coronary heart disease, stroke, and type 2 diabetes mellitus. Arch Intern Med 2005; 165:2644-50.

10. Mach F, Baigent C, Catapano AL, Koskinas KC, Casula M, Badimon L, et al. 2019 ESC/EAS Guidelines for the management of dyslipidaemias: lipid modification to reduce cardiovascular risk: The Task Force for the management of dyslipidaemias of the European Society of Cardiology (ESC) and European Atherosclerosis Society (EAS). Eur Heart J 2020;41:111-88.

11. World Medical Association. World medical association declaration of helsinki: Ethical principles for medical research involving human subjects. JAMA 2013;310:2191-4.

12. Saeedi P, Petersohn I, Salpea P, Malanda B, Karuranga S, Unwin N, et al. Global and regional diabetes prevalence estimates for 2019 and projections for 2030 and 2045: Results from the international diabetes federation diabetes atlas, $9^{\text {th }}$ edition. Diabetes Res Clin Pract 2019; $157: 107843$.

13. Satman I, Omer B, Tutuncu Y, Kalaca S, Gedik S, Dinccag N, et al. Twelve-year trends in the prevalence and risk factors of diabetes and prediabetes in Turkish adults. Eur J Epidemiol 2013;28:169-80.

14. Onat A, Türkmen S, Karabulut A, Yazıcı M, Can G, Sansoy V, et al. Combined hypercholesterolemia and hypertension among turkish adults: Prevalence and prediction of cardiovascular disease risk (TEKHARF Trial data). Arch Turk Soc Cardiol 2004;32:533-41.

15. Ozkara A, Turgut F, Kanbay M, Selcoki Y, Akcay A. Population-based cardiovascular risk factors in the elderly in Turkey: A cross-sectional survey. Cent Eur J Med 2008;3:173-8.
16. World Health Organization. Global Adult Tobacco Survey. Comparison Fact Sheet 2012; Turkey 2008\&2012. Available from: http://www. who.int/tobacco/surveillance/survey/gats/gats turkey 2008v2012 comparison_fact_sheet.pdf. [Last accessed on 2013 May 08].

17. Lv J, Yu C, Guo Y, Bian Z, Yang L, Chen Y, et al. Adherence to healthy lifestyle and cardiovascular diseases in the chinese population. J Am Coll Cardiol 2017;69:1116-25.

18. van Dam RM, Li T, Spiegelman D, Franco OH, Hu FB. Combined impact of lifestyle factors on mortality: Prospective cohort study in US women. BMJ 2008;337:a1440.

19. Loef M, Walach $H$. The combined effects of healthy lifestyle behaviors on all cause mortality: A systematic review and meta-analysis. Prev Med 2012;55:163-70.

20. Spring B, Ockene JK, Gidding SS, Mozaffarian D, Moore S, Rosal MC, et al. Better population health through behavior change in adults: A call to action. Circulation 2013;128:2169-76.

21. Lobelo F, Duperly J, Frank E. Physical activity habits of doctors and medical students influence their counselling practices. Br J Sports Med 2009;43:89-92.

22. Micha R, Khatibzadeh S, Shi P, Andrews KG, Engell RE, Mozaffarian D, et al. Global, regional and national consumption of major food groups in 1990 and 2010: A systematic analysis including 266 country-specific nutrition surveys worldwide. BMJ Open 2015;5:e008705.

23. Mozaffarian D. Dietary and policy priorities for cardiovascular disease, diabetes, and obesity: A comprehensive review. Circulation 2016;133:187-225.

24. Sanchis-Gomar F, Pérez LM, Joyner MJ, Löllgen H, Lucia A. Endurance exercise and the heart: Friend or foe? Sports Med 2016;46:459-66.

25. Ng M, Freeman MK, Fleming TD, Robinson M, Dwyer-Lindgren L, Thomson B, et al. Smoking prevalence and cigarette consumption in 187 countries, 1980-2012. JAMA 2014;311:183-92.

26. Choudhry NK, Avorn J, Glynn RJ, Antman EM, Schneeweiss S, Toscano M, et al. Full coverage for preventive medications after myocardial infarction. N Engl J Med 2011;365:2088-97.

27. Yusuf S, Islam S, Chow CK, Rangarajan S, Dagenais G, Diaz R, et al. Use of secondary prevention drugs for cardiovascular disease in the community in high-income, middle-income, and low-income countries (the PURE Study): A prospective epidemiological survey. Lancet 2011;378:1231-43. 